\title{
The Performance of Male Thin Tailed Sheep Given Tofu Waste in Concentrate
}

\author{
Emmy Kejora' ${ }^{1}$, Juli Mutiara Sihombing ${ }^{2}$ \\ ${ }^{1}$ Faculty of Agriculture \& Animal Husbandry, Tjut Nyak Dhien University, Medan, Indonesia \\ ${ }^{2}$ Faculty of Agriculture \& Animal Husbandry, Tjut Nyak Dhien University, Medan, Indonesia \\ Corresponding Author: Emmy Kejora
}

DOI: https://doi.org/10.52403/ijrr.20220215

\begin{abstract}
This study aims to determine the effect of giving tofu waste in concentrate on the performance of male thin tailed sheep. This study used 12 weaned male thin tailed sheep with an average initial body weight of $10.02 \pm 2.25 \mathrm{~kg}$. The research method used was RAL (Completely Randomized Design) with 4 treatments and 3 replications. The research treatments consisted of P0 (concentrate without tofu waste), P1 (10\% tofu waste in concentrate), P2 (20\% tofu waste in concentrate), P3 (30\% tofu waste in concentrate). Parameters observed included feed consumption, body weight gain and feed conversion. The research data were analyzed using the SAS (Statistical Analysis System) program. The results showed the average value of feed consumption and the highest average body weight gain was found in P2, namely $936.86 \mathrm{~g} / \mathrm{head} /$ day and $94.64 \mathrm{~g} / \mathrm{head} /$ day different significantly $(\mathrm{P}<0.05)$ with other treatments, the highest feed conversion was found in treatment P0 (concentrate without tofu waste) which was 17.47 and the lowest average was found in treatment P2 (concentrate $+20 \%$ tofu waste) which was equal to 10,13 . It was concluded that the best treatment in this study was P2 treatment (20\% tofu waste in concentrate).
\end{abstract}

Keywords: Concentrate, Male Sheep,

Performance, Tofu waste

\section{INTRODUCTION}

In general, sheep in Indonesia have low productivity, this happens because the quality of feed is low and is not available throughout the year so that the quantity of feed given is not sustainable. Livestock productivity is influenced by the quality and quantity of feed provided in a sustainable manner so that the availability of feed is needed throughout the year. For livestock, feed is not only a great need, but also fundamental in terms of quantity, quality and continuity (Utomo, 2015).

The main feed for sheep is forage and concentrate. The materials used as raw materials for the manufacture of concentrates are still imported from abroad, this causes the price of animal feed to be expensive. Therefore, efforts must be made to find alternative feeds that still have good nutrient content, which can come from agricultural waste or industrial waste processing agricultural products in Indonesia.

In addition to optimizing the utilization of potential resources owned by the agricultural industry, providing added economic value and supporting environmental sustainability through recycling and utilization of agricultural waste and or industrial waste processing agricultural products. In an effort to reduce feed costs, agro-industrial waste in Indonesia should be used to be processed and used as additional feed for sheep.

One of them is tofu waste. Tofu waste are waste from the soybean processing industry into tofu. Tofu waste contain high enough protein, therefore it is very good to be used as animal feed. According to Nuraini (2009), tofu waste 
contains $27.55 \%$ crude protein, $4.93 \%$ fat, $7.11 \%$ crude fiber, $44.50 \%$ BETN. Meanwhile, according to Tarmidi (2010), tofu waste contains $13.3 \%$ dry matter, crude protein $21 \%$, crude fiber $23.58 \%$, crude fat 10.49\%, NDF 51.93\%, ADF $250.63 \%$, ash $2.96 \%$, calcium $0.53 \%$, phosphorus $0.24 \%$ and gross energy $4.730 \mathrm{kcal} / \mathrm{kg}$.

According to Suprapti (2005) the water content of tofu waste is $85.31 \%$. Because the tofu waste still have water content and high protein content, it causes tofu waste to easily rot and get mouldy, so they are not liked by livestock within 2-3 days. However, tofu waste can be dried and made into flour so that the water content drops to $12-15 \%$. To get dry tofu waste, it is done by drying it in the sun or putting it in the oven to dry. Once it becomes flour, its shelf life will be longer and it will make it easier to mix it with other feed ingredients.

Tofu waste for animal feed have been used and researched for a long time. Duldjaman (2004) has conducted research on the use of tofu waste for local sheep. In this study, sheep were given field grass and dry tofu waste ranging from 100, 200 and 300 grams. The results reported that increasing tofu waste had an effect on dry matter consumption. Likewise, increased consumption of TDN and protein. It was further reported that giving tofu waste to sheep whose main diet was grass field was able to increase the coefficient of feed use and increase in live weight. High live weight gain resulted in sheep with good body condition.

This study aims to determine the percentage of tofu waste that can be added to sheep concentrate to improve sheep performance. In addition, the use of tofu waste can be used as an alternative feed for sheep. The results of this study are important outcomes regarding the formulation of a new ration, a mixture of commercial rations which is partially replaced with tofu waste. In addition to the ration formula, scientific publications will also be produced on the use of tofu waste in sheep concentrate. This information will be very useful in the development of science in the field of animal husbandry, especially sheep farming, and become a consideration for sheep breeders who want to provide tofu waste as an alternative feed to replace part of commercial feed. Besides, the use of tofu waste will greatly help reduce environmental pollution.

\section{MATERIALS AND METHOD}

The research was conducted from April to August 2021 at CV. Sheep Waringin Center Langkat District, North Sumatra, Indonesia.

The materials used in this study were 12 weaned male thin tailed sheep with an average initial body weight of $10.02 \pm 2.25$ $\mathrm{kg}$. Field grass and concentrate consisting of tofu waste, coconut meal, fine corn, rice bran, molasses, ultra minerals, urea and livestock multivitamins. Medicines are worm medicine, bloating medicine, eye ointment, vitamin B complex and disinfectant and drinking water.

The tools used are 12 individual cages with a size of $150 \mathrm{~cm}$ x $75 \mathrm{~cm} \times 100$ $\mathrm{cm}$ which are equipped with feed and drinking places. Room thermometer to measure the temperature inside the cage and the temperature outside the cage; ideal life brand electronic scales with a capacity of five kilograms with a sensitivity of one gram to weigh feed and feed residue; hanging scales with a capacity of $25 \mathrm{~kg}$ with a sensitivity of 100 grams for weighing sheep; brooms, shovels and other tools for cleaning cages; tarpaulin for drying tofu waste; the sickle is used as a lawn mower; plastic to accommodate the rest of the feed; besek to dry leftover feed and stationery.

The research design used was RAL (Completely Randomized Design) with 4 treatments and 3 replications. The research treatment consisted of:

$\mathrm{P} 0=$ Concentrate without tofu waste

$\mathrm{P} 1=10 \%$ tofu waste in concentrate

$\mathrm{P} 2=20 \%$ tofu waste in concentrate

$\mathrm{P} 3=30 \%$ tofu waste in concentrate 
The research variables measured were feed consumption (g/head/day), daily body weight gain (g/head/day) and feed conversion.

The data obtained were analyzed by means of variance and if the treatment had a significant effect on the observed variables, the analysis was continued with Duncan's double distance further test using the help of the SAS program.

\section{RESULTS AND DISCUSSION}

The recapitulation of research results on each parameter of feed consumption, body weight gain and feed conversion in male thin tailed sheep using tofu waste in the ration is presented in table 1 .

Table 1. Recapitulation of the results of the addition of tofu waste in the ration male thin tailed sheep

\begin{tabular}{|c|c|c|c|c|c|}
\hline No. & Variable & & Treatment & & \\
\hline & & P0 & P1 & $\mathbf{P 2}$ & P3 \\
\hline 1. & Feed consumption (g/head/day) & $660.25^{\mathrm{b}} \pm 31,42$ & $866.52^{\mathrm{a}} \pm 51,40$ & $936.86^{\mathrm{a}} \pm 5,82$ & $930.97^{\mathrm{a}} \pm 42,55$ \\
\hline 2. & Body weight gain ( $\mathrm{g} / \mathrm{head} /$ day) & $38.56^{\mathrm{c}} \pm 5,38$ & $74.11^{\mathrm{b}} \pm 15,32$ & $94.64^{\mathrm{a}} \pm 14,14$ & $65.44^{\mathrm{b}} \pm 13,85$ \\
\hline 3. & Feed conversion & $17.47^{\mathrm{b}} \pm 2,61$ & $12.13^{\mathrm{a}} \pm 2,15$ & $10.13^{\mathrm{a}} \pm 1,58$ & $14.69^{\mathrm{s}} \pm 2,25$ \\
\hline
\end{tabular}

The mean values followed by different superscripts in the same row showed significantly different results $(\mathrm{P}<0.05)$.

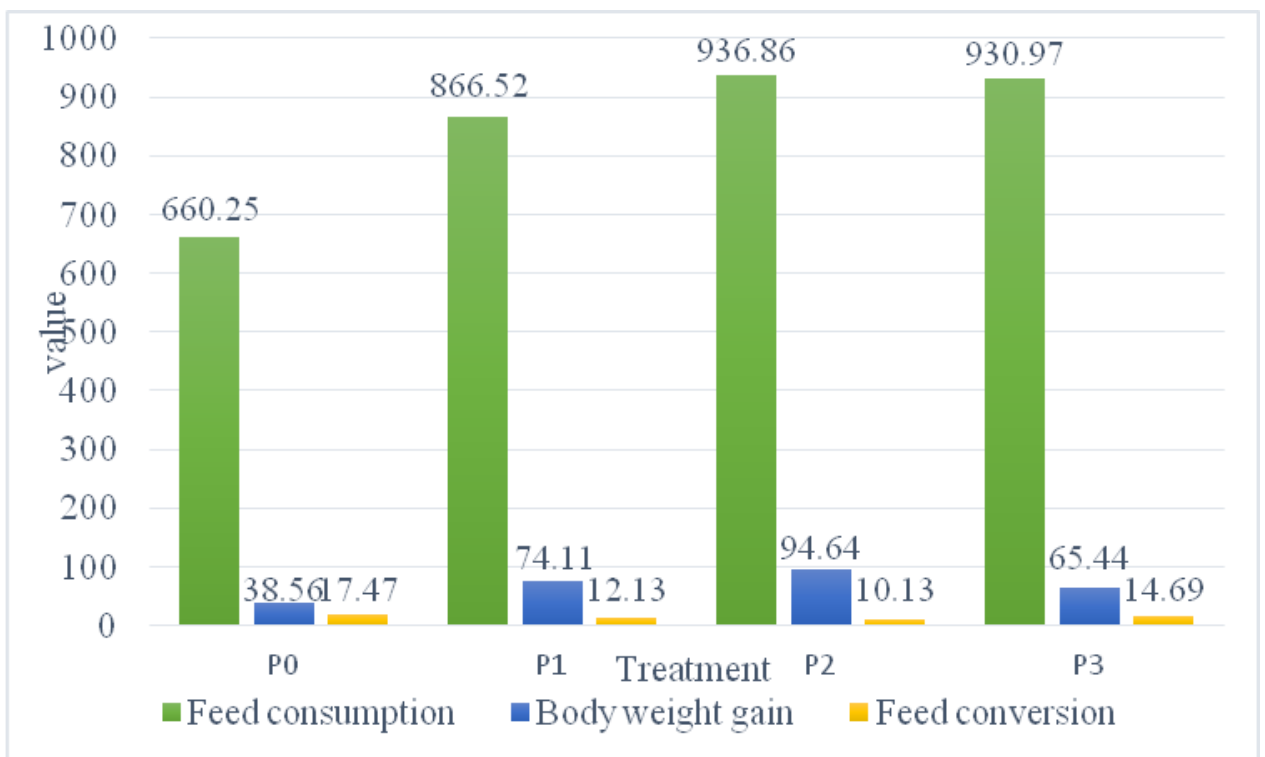

Figure 1. Graph of the performance variable value of male thin tailed sheep as a result of research treatment

\section{a. Feed Consumption}

Feed consumption is an indicator of livestock liking the feed given for basic life and production. Therefore, if the value of feed consumption is high, it is also expected to be followed by an increase in livestock production performance. The average consumption of male thin-tailed sheep during the study can be seen in Table 1 .

The average feed consumption of sheep during the study (Table 1) ranged from $660-936 \mathrm{~g} / \mathrm{head} / \mathrm{day}$ or about $3-4.5 \%$ of the average live weight $(11.2 \mathrm{~kg})$. The average feed consumption of tofu waste in the concentrate of male thin tailed sheep is almost the same as the average feed consumption in the feed treatment reported by Metkono et al. (2011), which varied between $583-774 \mathrm{~g} / \mathrm{head} /$ day. Kearl (1982) in terms of feed consumption, suggested that growing sheep with a live weight of 20 $\mathrm{kg}$ and an increase in live weight of $100 \mathrm{~g}$ required $410 \mathrm{~g}$ of dry matter daily or $3.5 \%$ live weight. Thus, the feed given in this study met the criteria recommended by Kearl (1982). 
The results of the variance showed that the treatment had a significant effect on feed consumption. The results (Figure 1) showed that the highest average feed consumption was found in P2 (20\% tofu waste in concentrate) which was 936.86 $\mathrm{g} /$ head/day there was a significant difference $(\mathrm{P}<0.05)$ with $\mathrm{P} 0, \mathrm{P} 1, \mathrm{P} 3(660.25$ $\mathrm{g} /$ head/day, $\quad 866.52 \mathrm{~g} / \mathrm{head} /$ day, $\quad 930.97$ $\mathrm{g} /$ head/day, fish/day). The treatment using concentrate without tofu waste (P0) had lower consumption than the concentrate added with tofu waste (P1, P2 and P3). The higher the use of concentrate plus dry tofu waste in the feed indicates an increase in feed consumption. These results indicate that the research feed has palatability. Parakkasi (1999) explained that feed palatability is one of the factors that affect the amount of feed consumption and the ability of livestock to consume dry matter contained in feed related to the physical capacity of the stomach and digestive tract conditions, so that the level of feed consumption in ruminants is strongly influenced by environmental factors, livestock conditions and feed factors.

\section{b. Body Weight Gain}

The highest average body weight gain was found in treatment P2 (20\% tofu waste in concentrate) (Table 1), namely $94.64 \mathrm{~g} / \mathrm{head} /$ day and significantly different $(\mathrm{P}<0.05)$ with P0, P1, P3 (38.56 g/head/day, $74.11 \mathrm{~g} / \mathrm{h}$ ad/day, $65.44 \mathrm{~g} / \mathrm{head} /$ day). Analysis of the diversity of body weight gain showed that feeding with tofu waste concentrate had a very significant effect $(p<0.05)$ on the weight gain of male thin tailed sheep. For comparison, Metkono et al. (2011) using 50\% field grass $+50 \%$ tofu waste resulted in the first daily body weight of $73 \mathrm{~g} / \mathrm{head} / \mathrm{day}$. These data indicate that the provision of a ration consisting of $50 \%$ field grass $+50 \%$ tofu waste can increase body weight gain and daily body weight gain of sheep during the study. Meanwhile, Kardaya et al (2001) which used $70 \%$ grass and $30 \%$ concentrate with the addition of 5 $\mathrm{mg} \mathrm{Zn} / \mathrm{kg} \mathrm{Zn}$ protein in Alltech USA production, resulted in an increase in daily live weight of $83.74 \mathrm{~g}$ head/day or an increase of $32.63 \%$ compared to with control.

The P2 treatment had a high consumption so that body weight gain also increased this was related to the level of livestock palatability. According to Nursasih (2005), the increase in body weight of ruminants is strongly influenced by the quality and quantity of feed, this means that the assessment of body weight gain is proportional to the ration consumed. Added by Parakkasi (1999) that one of the factors that affect body weight gain is feed consumption, the higher the amount of feed consumed, the higher the rate of livestock growth. This shows that giving concentrate with the addition of dry tofu waste as much as $20 \%$ has a good effect on the growth of male thin tailed sheep.

\section{c. Feed Conversion}

Feed conversion can be determined by comparing the amount of feed consumed with the body weight gain produced during a certain rearing period or by comparing the resulting body weight gain with the amount of feed consumed in a certain rearing period. The lower the feed conversion rate, the more efficiently feed is used to produce body weight gain. In other words, the greater the feed efficiency number, the more efficient the ration used to produce body weight gain. The total feed conversion for each treatment during the study is presented in Table 1.

From Figure 1, it is known that the highest feed conversion was found in treatment P0 (concentrate without tofu waste) significantly different $(\mathrm{P}<0.05)$ which was 17.47 and the lowest average was found in treatment P2 (20\% tofu waste in concentrate) which is 10.13 . From these data it can be concluded that treatment P2 (20\% tofu waste in concentrate) has the best feed conversion value compared to treatment P0 (concentrate without tofu waste). Feed conversion can be used to determine production efficiency because it 
is closely related to production costs, the lower the feed conversion value, the higher the efficiency of feed use. Juarini et al (1995) stated that the higher the feed conversion value, the higher the feed used to increase body weight per unit weight or reduce feed efficiency.

\section{CONCLUSION}

The addition of dry tofu waste in the concentrate of male thin tailed sheep had a significant effect on feed consumption, body weight gain and feed conversion. Increasing the provision of research treatment can increase feed consumption and body weight gain, and tends to improve ration conversion. The best treatment was P2 (20\% tofu waste in concentrate).

\section{Acknowledgement: None}

\section{Conflict of Interest: None}

\section{Source of Funding: None}

\section{Ethical Approval: Approved}

\section{REFERENCES}

1. Duldjaman.M. 2004. Penggunaan ampas tahu untuk meningkatkan gizi pakan domba lokal. Media Peternakan. 27.3: 107-110.

2. Juarini, E. I. I. Hasan, B. Wibowo, dan A. Tahar. 1995. Penggunaan konsentrat komersial dalam ransum domba di pedesaan dengan agroekosistem campuran (sawah tegalan) di Jawa Barat. Pros. Seminar Nasional Sains dan Teknologi Peternakan. Balai Penelitian Ternak. Bogor. hal. 176181.

3. Kardaya D, Supriyati, Suryahadi dan T Toharmat. 2001. Pengaruh suplementasi $\mathrm{Zn}$-proteinat,Cu-proteinat ammoniumolibdat terhadap performans domba lokal. Media Peternakan 24: 1-9.

4. Kearl LC. 1982. Nutrient Requirements of Ruminants in Developing Countries. Int'1 Feedstuff Inst . Utah Agric. Exp.Sta.USU. Logan Utah . USA.

5. Metkono OAF, D Kardaya, dan D Sudrajat.2011. Performa Domba Lokal Yang Diberi

6. Ransum Rumput Lapang Dan Ampas Tahu Yang Dipelihara Secara Tradisional. Jurnal Pertanian.

7. Nuraini, S.A.Latif, dan Sabrina. 2009. Potensi monascus purpureus untuk membuat pakan kaya karotenoid monakolin dan aplikasinya untuk memproduksi telur unggas rendah kolesterol. Working Paper. Fakultas Peternakan.

8. Nursasih, E. 2005. Kecernaan zat makanan dan efisiensi pakan pada kambing Peranakan Etawah yang mendapat ransum dengan sumber serat berbeda. Skripsi. Fakultas Peternakan Institut Pertanian Bogor. Bogor.

9. Parakkasi, A. 1999. Ilmu Nutrisi dan Makanan Ternak Ruminansia. Universitas Indonesia, Jakarta.

10. Suprapti, M. L. 2005. Pembuatan Tahu. Kanisius: Yogyakarta

11. Tarmidi, A.R. 2010. Penggunaan Ampas Tahu dan Pengaruhnya pada Pakan Ruminansia. Layanan dan Produk Umban Sari Farm.

12. Utomo, R.2015. Konservasi Hijauan Pakan dan Peningkatan Kualitas Bahan Pakan Berserat Tinggi. Gadjah Mada University Press. Yogyakarta.

How to cite this article: Emmy Kejora, Juli Mutiara Sihombing. The performance of male thin tailed sheep given tofu waste in concentrate. International Journal of Research and Review. 2022; 9(2): 107-111. DOI: https:// doi.org/10.52403/ijrr.20220215 